$$
\begin{array}{r}
\text { Conf }-950868 \\
1021 \\
\text { Mark R. Wood } \\
\text { Rocky Mountain Remediation Services } \\
\text { Bldg. 080, P.O. Box } 464 \\
\text { Golden, CO 80402-0464 } \\
\text { (303)966-8784 fax (303)966-8663 }
\end{array}
$$

\title{
Regulatory Acceptance of the Proposed Well Abandonment Program for the Present Landfill, Operable Unit 7, Rocky Flats Environmental Technology Site, Golden, Colorado
}

\section{ABSTRACT}

The regulatory agencies approved a well abandonment program for the Present Landfill, Operable Unit (OU) 7 at the Rocky Flats Environmental Technology Site, only three months after preparation. The proposed well abandonment program consists of abandoning 26 of the 54 existing monitoring wells in OU 7 that are currently sampled quarterly as Resource Conservation and Recovery Act (RCRA) compliance wells or sitewide groundwater protection wells. Well abandonment was proposed on the basis that the purpose of each well has been fulfilled, the wells fall under the footprint of the landfill cap, the presence of the wells would compromise the integrity of the cap because holes would have to be cut in the synthetic liner, and unequal compaction of the fill material around the wells would potentially cause differential settlement of the cap.

The well abandonment proposal was prepared in December 1994 and submitted to the U.S. Department of Energy Rocky Flats Field Office (DOE-RFFO) on December 21, 1994. The DOE-RFFO reviewed, approved, and submitted the proposal to the lead regulatory agency, the Colorado Department of Public Health and Environment (CDPHE), on January 13, 1995. The CDPHE approved the well abandonment proposal for OU 7 on February 13, 1995.

The proposal provided the technical justification to abandon the wells in place. The timely approval of the proposal by the regulatory agencies will allow the abandonment of the wells during fiscal year 1995 under the sitewide Well Abandonment and Replacement Program (WARP). Cost savings resulting from a decrease in the number of wells to be sampled under the groundwater monitoring program are estimated at $\$ 416,000$ per year. This paper presents a summary of the well abandonment program, discusses the timely approvals required for implementation, and present the potential cost savings that can be achieved through implementation of the program.

\section{INTRODUCTION}

The Present Landfill, Operable Unit (OU) 7 at the Rocky Flats Environmental Technology Site, is located north of the industrial area at the headwaters of No Name Gulch (Figure 1). The landfill opened in 1968 and will continue to be used for waste disposal until

Regulatory Acceptance of the Proposed Well Abandonment Program for the Present Landfill, Operable Unit 7, Rocky Flats Environmental Technology Site, Golden, Colorado 


\section{DISCLAIMER}

Portions of this document may be illegible in electronic image products. Images are produced from the best available original document. 


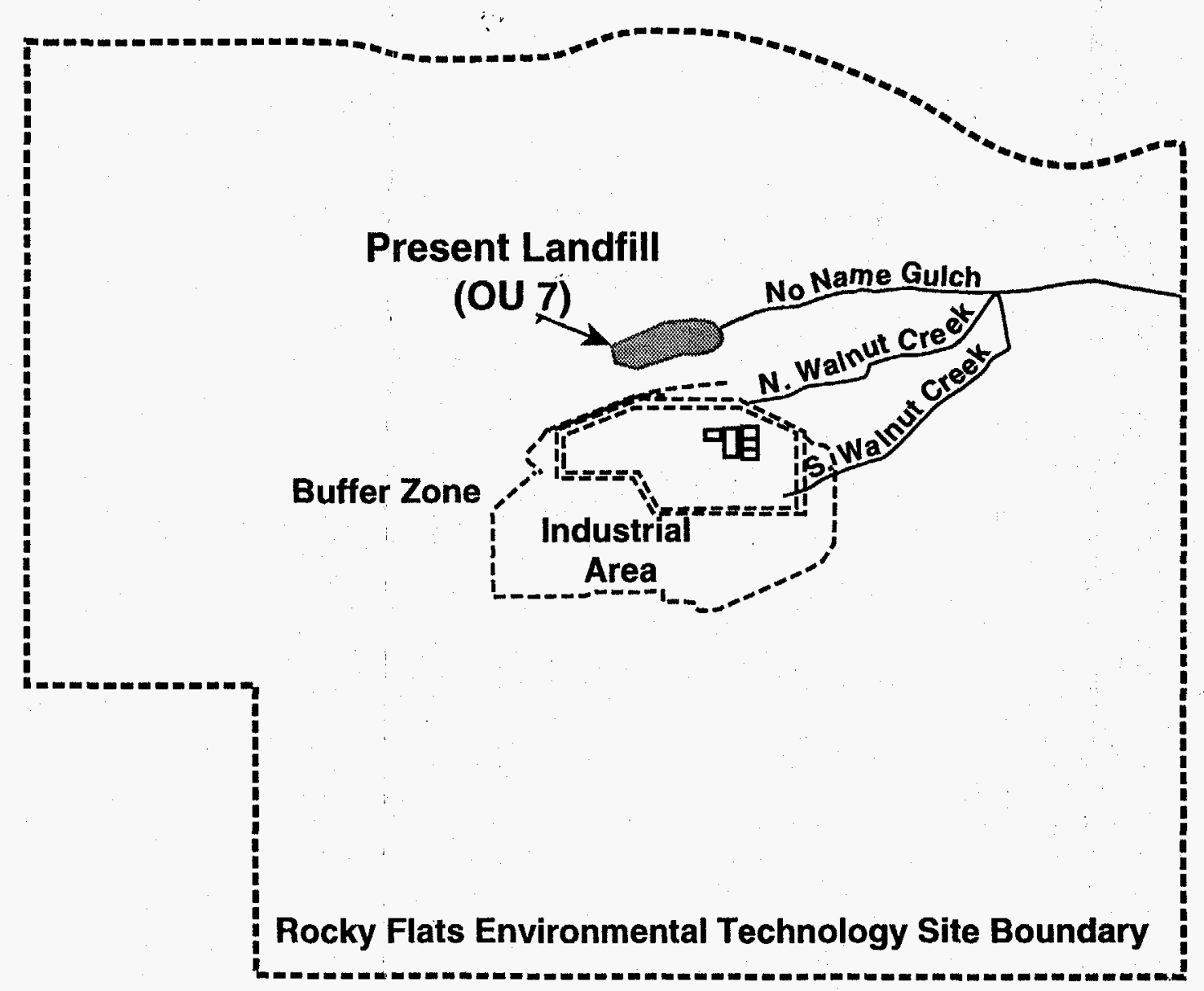

Figure 1

Location of Present Landfill 
Mark R. Wood

Rocky Mountain Remediation Services. Bldg. 080, P.O. Box 464 Golden, CO 80402-0464 (303)966-8784 fax (303)966-8663

closure in 1997. Hazardous and nonhazardous waste streams were disposed in the landfill from 1968 to 1986. As of November 1986, waste streams identified as hazardous were no longer disposed in the landfill. Since 1986, waste streams disposed are similar to those disposed in a municipal landfill. Based on the areal and vertical extent of waste and soil cover, the total volume of material in the landfill is estimated to be 415,000 cubic yards. By closure in 1997, the total volume of waste and fill material will be approximately 540,000 cubic yards.

OU 7 is undergoing final closure pursuant to the Interagency Agreement among DOE, CDPHE, and the U.S. Environmental Protection Agency (EPA). A presumptive remedy approach was adopted by DOE, CDPHE, and EPA for streamlined site characterization and remediation. The presumptive remedy for Comprehensive Environmental Response, Compensation and Liability Act (CERCLA) municipal landfill sites is containment of the landfill mass to prevent direct contact with soil or debris, reduce contaminant leaching, and control surface-water runoff and erosion (1). Containment will be achieved by institutional controls and a landfill cover (2). The remedy requires abandonment of existing monitoring wells that faH under the proposed footprint of the landfill cover.

\section{DESCRIPTION OF THE EXISTING MONITORING-WELL NETWORK}

Currently there are 60 groundwater monitoring wells (54 active and 6 abandoned) located at or near the Present Landfill (Figure 2). Twenty-seven were installed as RCRA regulatory wells:and are currently sampled quarterly for the RCRA groundwater monitoring program at the Present Landfill. Twenty-five were installed as CERCLA characterization wells and are currently sampled quarterly for the sitewide groundwater monitoring program. One was installed as a special purpose well and is also currently sampled quarterly. Five damaged RCRAcharacterization wells were abandoned in 1993. One damaged RCRA-characterization well was replaced in 1993. The purpose of all 60 wells installed at or near the Present Landfill is summarized below (3).

In 1986, two well pairs were installed to characterize the hydrogeology in the vicinity of the landfill (Figure 2). One well pair was installed upgradient (0986 and 1086) and the other downgradient (0786 and 0886) of the landfill. In addition, wells 0586 and 0686 were installed downgradient along No Name Gulch above the confluence with North and South Walnut Creeks.

In 1987, 17 monitoring wells were installed to characterize the site and determine the effectiveness of the groundwater intercept system and slurry walls (Figure 2). Well 5887 was installed upgradient immediately west of the landfill. Eight wells $(5987,6087,6187,6287,6387$, 6487,6587 , and 6687) were installed across the groundwater intercept system. Five wells (6787, $6887,7087,7187$, and 7287 ) were installed to evaluate the north and south slurry walls. Three

\footnotetext{
Regulatory Acceptance of the Proposed Well Abandonment Program for the Present Landfill, Operable Unit 7, Rocky Flats Environmental Technology Site, Golden, Colorado
} 


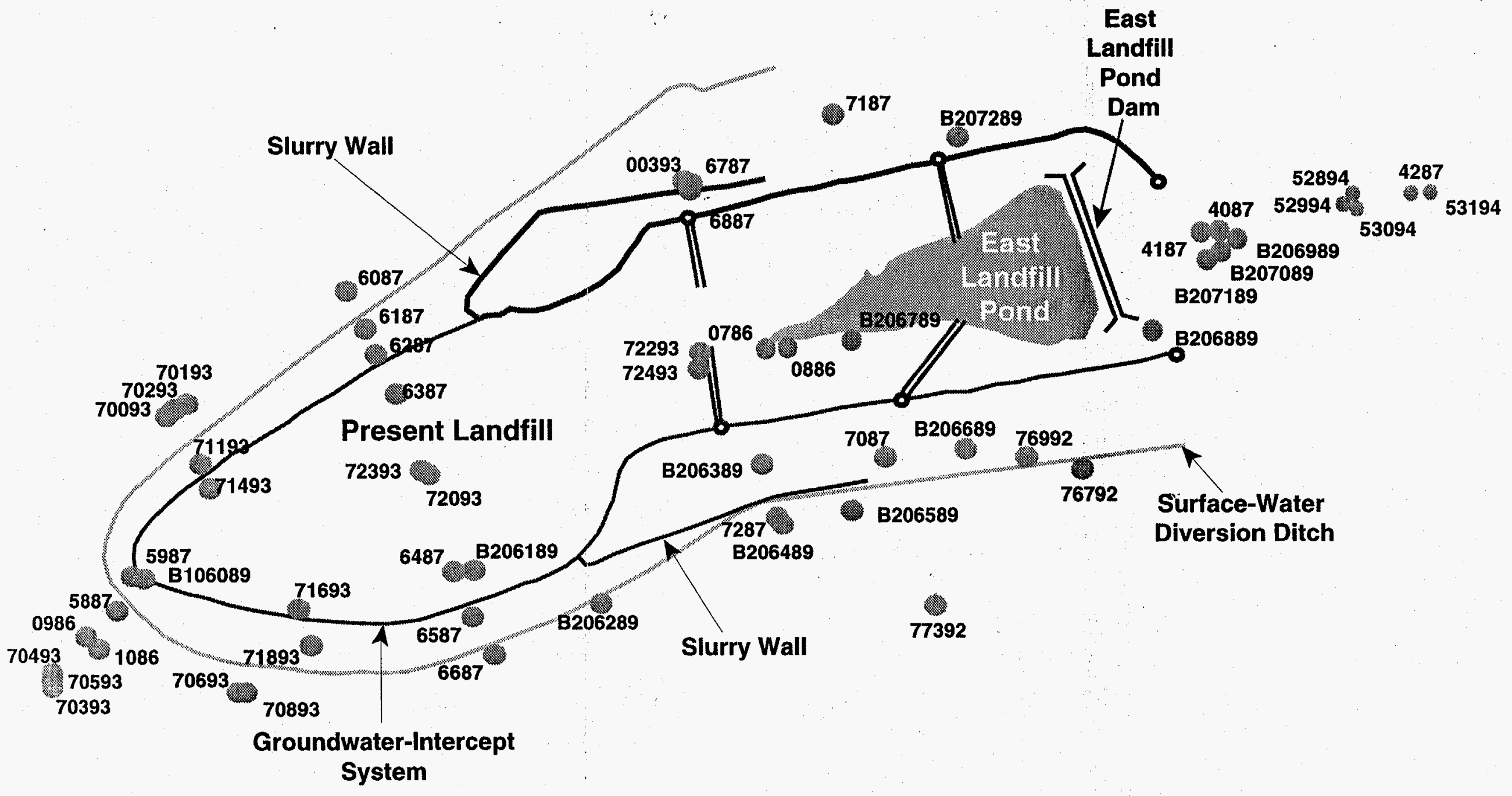

Figure 2

Existing Monitoring-Well Network at OU 7 
Mark R. Wood

Rocky Mountain Remediation Services

Bldg. 080, P.O. Box 464

Golden, CO 80402-0464

(303) $966-8784$ fax (303) $966-8663$

wells $(4087,4187$, and 4287) were installed downgradient of the East Landfill Pond embankment to monitor groundwater leaving the landfill.

In 1989, 13 monitoring wells were installed (Figure 2). Well B106089 replaced well 5987 , which was drilled into the clay seal of the groundwater intercept system. Six wells (B206189, B206289, B206589, B206689, B206789, and B207289) were drilled to locate and monitor potential subcropping sandstones around the East Landfill Pond. Two wells (B206389 and B206489) were installed to evaluate the effectiveness of the slurry walls. Two wells (B206889 and B206989) were installed to monitor the groundwater in the vicinity of the discharge points for the groundwater intercept system, and two wells (B207089 and B207189) were installed to monitor bedrock sandstones encountered in wells 0886 and 4187.

Three CERCLA characterization wells (76792, 76992, and 77392) were installed and sampled in 1993 for the Phase I RCRA Facility Investigation/Remedial Investigation (RFI/RI) at OU 6 (Figure 2). One well (00393) was installed under WARP to replace a damaged RCRA regulatory well (6787). Sixteen CERCLA characterization wells (70093, 70193, 70293, 70393, $70493,70593,70693,70893,71193,71493,71693,71893,72093,72293,72393$, and 72493) were installed and sampled in 1993 for the Phase I RFI/RI at OU 7. Four CERCLA characterization wells (52894, 52994, 53094, and 53194) were installed for the Phase II RFI/RI at OU 7. The Phase II wells were sampled monthly for four months beginning in December 1994. After the CERCLA characterization was completed, the wells were sampled quarterly under the sitewide groundwater monitoring program.

\section{TECHNICAL JUSTIFICATION FOR WELL ABANDONMENT}

DOE proposed abandoning 26 existing monitoring wells under the proposed footprint of the landfill cover. These wells would compromise the integrity of the cover because holes would have to be cut in synthetic cover layers around each well. The presence of monitoring wells in the landfill after final closure would potentially result in differential settlement of the cap because the fill material could not be equally compacted around the well casing. These 26 wells were installed to characterize the site, determine the effectiveness of the groundwater intercept system and slurry walls, monitor potential subcropping sandstones around the East Landfill Pond, and characterize leachate within the landfill. The original purpose of each of these wells has been fulfilled, and the wells are no longer needed in the groundwater monitoring network (Figure 3) (3).

Regulatory Acceptance of the Proposed Well Abandonment Program for the Present Landfill, Operable Unit 7, Rocky Flats Environmental Technology Site, Golden, Colorado 


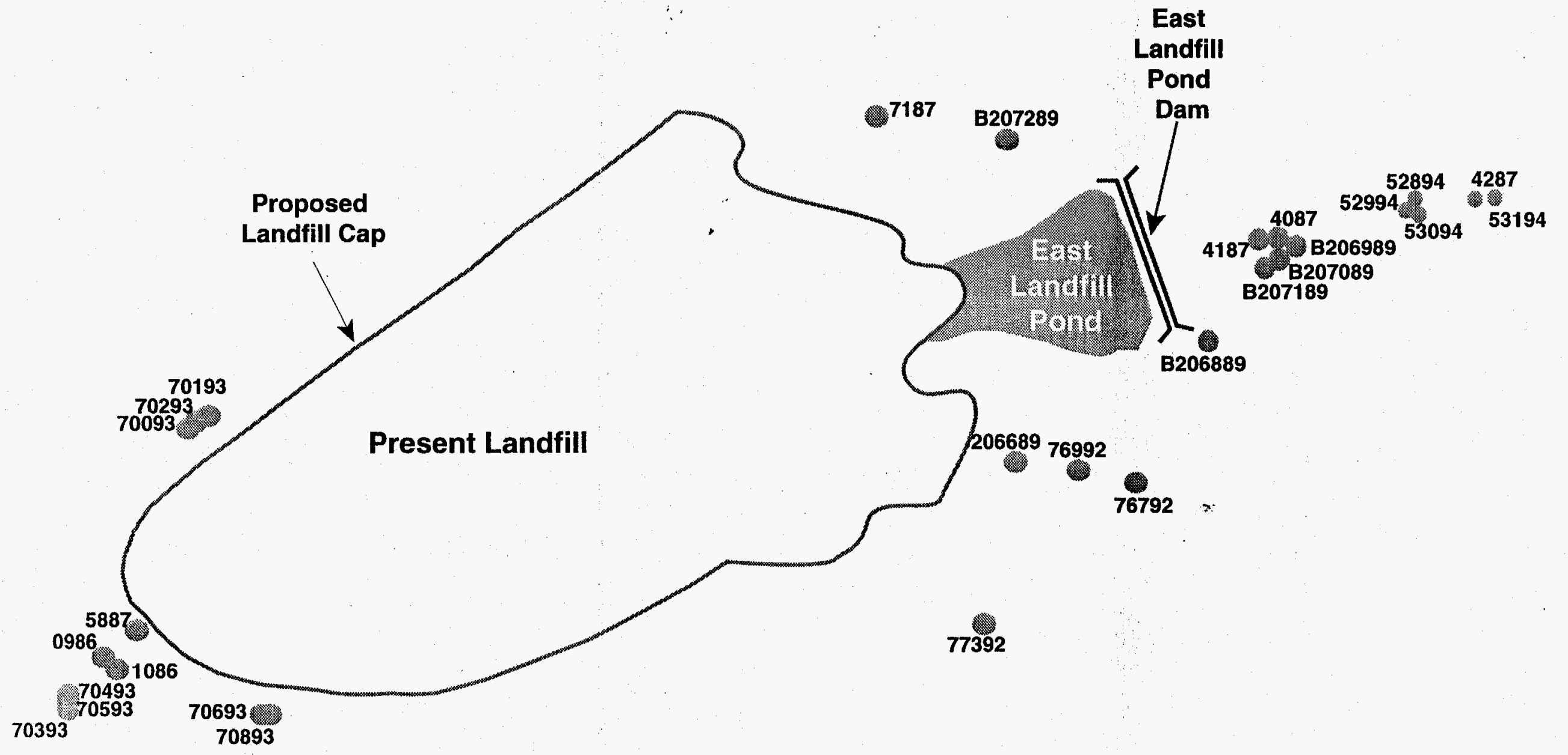

Figure 3

Monitoring-Well Network after Wèll Abandonment 
Mark R. Wood

Rocky Mountain Remediation Services Bldg. 080, P.O. Box 464

Golden, CO 80402-0464

(303)966-8784 fax (303)966-8663

Wells proposed for abandonment are as follows:

\begin{tabular}{|l|l|l|l|}
\hline 0786 & 6587 & B206489 $^{*}$ & 72093 \\
\hline 0886 & 6687 & B206589 & 72293 \\
\hline 5887 & 6887 & B206789 & 72393 \\
\hline 6087 & 7087 & 71193 & 72493 \\
\hline 6187 & 7287 & 71493 & 00393 \\
\hline 6287 & B106089 & 71693 & \\
\hline 6487 & B206289 & 71893 & \\
\hline
\end{tabular}

Wells 0786 and 0886 were installed to characterize the hydrogeology downgradient of the landfill. Although these wells are currently designated as RCRA regulatory wells, the original purpose of the wells has been fulfilled, new wells have been installed farther downgradient of the landfill, and the wells are near the location of the seep collection system that will be constructed in fall 1995 and may be damaged during construction.

Wells 5887, 6087, 6187, 6287, 6487, 6587, 6687, 6887, 7087, and 7287 were installed to characterize the site and determine the effectiveness of the groundwater intercept system. Although these wells are currently designated as RCRA regulatory wells, the original purpose of the wells has been fulfilled. The groundwater intercept system is not operating effectively and will be repaired as a maintenance action before landfill closure.

$\therefore$ Wells B106089, B206289, B206489, B206589, and B206789 were installed to evaluate the effectiveness of the groundwater intercept system and slurry walls and to locate and monitor potential subcropping sandstones. These wells are also currently designated as RCRA regulatory wells. Again, the original purpose of the wells has been fulfilled.

Wells 71193, 71493, 71693, 71893, 72093, 72293, 72393, and 72493 are CERCLA characterization wells that were installed at OU 7 to characterize leachate. The leachate has been adequately characterized. Well 00393 was installed as a replacement well to evaluate the effectiveness of the groundwater intercept system. The groundwater intercept system is not operating effectively and will be repaired.

\section{DESCRIPTION OF THE WELL-ABANDONMENT PROGRAM}

As the DOE plan demonstrates, the purpose of these 26 wells had been fulfilled and the wells are no longer necessary components of the existing monitoring-well network. As part of the pre-construction site improvement process to facilitate cap construction, DOE proposed to

Regulatory Acceptance of the Proposed Well Abandonment Program for the Present Landfill, Operable Unit 7, Rocky Flats Environmental Technology Site, Golden, Colorado 
abandon these 26 wells in 1996 under WARP. DOE proposed to discontinue quarterly monitoring of these wells in 1995, which will result in significant cost savings over time.

All wells approved for abandonment will be plugged and abandoned in accordance with Environmental Management Department Operating Procedures. Wells will be abandoned in place by filling the casing with bentonite grout and topping it off with concrete. To allow for settlement of the landfill waste and prevent the well casing from damaging the cap, the polyvinyl chloride (PVC) casing will be cut off at least 3 feet below the existing grade. A water-tight cover will be permanently fixed to the top of the casing. The protective casing and the concrete well pad will be removed. Fill material will be placed above the well cover to the surface.

Abandonment of wells in place is recommended to limit the volume of drill cuttings or investigation-derived material (IDM) generated. The small amount of IDM generated will be containerized in accordance with Environmental Management Department Operating Procedures during well abandonment. DOE proposed placing all of the OU 7 and WARP IDM in the landfill before the final cap is constructed. Disposal of the IDM in the landfill will provide additional cost savings.

\section{AGENCY INTERACTION}

The well abandonment proposal was prepared by EG\&G Rocky Flats, Inc. in December 1994 and submitted to the DOE Rocky Flats Field Office (DOE-RFFO) on December 21, 1994. DOE:RFFO reviewed, approved, and submitted the proposal to the lead regulatory agency, CDPHE, on January 13,1995, and CDPHE approved the well abandonment proposal for OU 7 on February 13, 1995.

\section{COST SAVINGS}

Groundwater samples for the RCRA program are collected on a quarterly basis beginning on January 1. Timely approval of proposal to stop sampling the 26 RCRA regulatory or sitewide groundwater-monitoring wells as of April 1, 1995 resulted in significant cost savings for fiscal year (FY) 1995. Savings in analytical costs of $\$ 3,846$ per analyte suite per well were realized for the two sampling quarters in FY95, the second and third sampling quarters of calendar year 1995. The cost per analyte suite $(\$ 3,846)$, multiplied by 26 wells, multiplied by two sampling quarters brings the total savings to $\$ 200,000$ for FY95. The reduced groundwater-monitoring program in the landfill, well abandonment in place, and disposal of IDM generated during well abandonment into the landfill will result in additional cost savings in FY96.

Regulatory Acceptance of the Proposed Well Abandonment Program for the Present Landfill, Operable Unit 7, Rocky Flats Environmental Technology Site, Golden, Colorado 
Mark R. Wood

Rocky Mountain Remediation Services Bldg. 080, P.O. Box 464

Golden, CO 80402-0464

(303)966-8784 fax (303)966-8663

\section{LESSONS LEARNED}

The regulatory agencies provided timely approval of a well abandonment program for the Present Landfill only three months after preparation. The total savings to DOE and the U.S. taxpayer for FY95 is $\$ 200,000$ in reduced analytical costs.

Lessons learned from the well abandonment proposal are as follows: (1) using a proactive approach among DOE, CDPHE, and EPA allowed for acceleration of the project schedule and resulted in a significant cost savings for DOE; (2) researching the purpose and sampling history of each well allowed development of a proposal with adequate technical justification; and (3) carrying through with the well abandonment after receiving agency approval sends a clear message to the regulatory agencies about DOE's commitment to environmental restoration.

\section{REFERENCES}

1. U.S. Environmental Protection Agency, Presumptive Remedy for CERCLA Municipal Landfill Sites, Directive No. 9355.0-49FS, PB 93-963339, September 1993.

2. U.S. Department of Energy, Draft Phase I IM/IRA Decision Document for Operable Unit No. 7, Present Landfill and Inactive Waste Storage Area, July 1995.

3. U.S. Department of Energy, Final Work Plan Technical Memorandum for Operable Unit No. 7, Present Landfill and Inactive Hazardous Waste Storage Area, September 1994.

\section{CO-AUTHORS:}

Vaag, Myra K., The S.M. Stoller Corporation, 5700 Flatiron Parkway, Boulder, CO 80301-5718, (303)546-4417, fax (303)443-1408

\section{DISCLAIMER}

This report was prepared as an account of work sponsored by an agency of the United States Government. Neither the United States Government nor any agency thereof, nor any of their employees, makes any warranty, express or implied, or assumes any legal liability or responsibility for the accuracy, completeness, or usefulness of any information, apparatus, product, or process disclosed, or represents that its use would not infringe privately owned rights. Reference herein to any specific commercial product, process, or service by trade name, trademark, manufacturer, or otherwise does not necessarily constitute or imply its endorsement, recommendation, or favoring by the United States Government or any agency thereof. The views and opinions of authors expressed herein do not necessarily state or reflect those of the United States Government or any agency thereof.

Regulatory Acceptance of the Proposed Well Abandonment Program for the Present Landfill, Operable Unit 7, Rocky Flats Environmental Technology Site, Golden, Colorado 